\title{
Teaching Ecosystem Design: Teachers' Satisfaction with the Integrated Course Service System
}

\author{
Meng-Hua Li ${ }^{1,2}$, Ming-Chien Hung ${ }^{3}$, Wen-Hsu Hsian ${ }^{4}$, Won-Fu Heung ${ }^{4}$, Mai-Lun Chiu ${ }^{5, *}$ (1) \\ and Shen-Tsu Wang ${ }^{6}$ \\ 1 Department of Industrial Management \& Institute of Industrial Engineering and Management, \\ National Formosa University, Huwei, Yunlin 63201, Taiwan \\ 2 Smart Machine and Intelligent Manufacturing Research Center, National Formosa University, Huwei, \\ Yunlin 63201, Taiwan \\ 3 Department of Information Management, Nanhua University, No.55, Sec.1 Nanhau Rd., Dalin Township, \\ Chiayi County 62248, Taiwan \\ 4 Department of Applied Digital Media, WuFeng University, No.117, Sec. 2, Jianguo Rd., \\ Minhsiung Township, Chiayi County 621, Taiwan \\ 5 Department of Information Management, National Penghu University of Science and Technology, No.300, \\ Liuhe Rd., Magong City, Penghu County 88046, Taiwan \\ 6 Department of Commerce Automation and Management, National Pingtung University, \\ Pingtung 90003, Taiwan \\ * Correspondence: mellenchiu@gmail.com
}

Received: 16 June 2019; Accepted: 26 August 2019; Published: 1 September 2019

check for updates

\begin{abstract}
In order to support teachers preparing their teaching resources, a teaching ecosystem for developing an online service system to acquire teaching materials, the Ministry of Education (MOE) in Taiwan, implemented an Integrated Course Service System (ICSS) to assist teachers in searching for instructional resources from distributed Educational Six Learning Networks (ESLN) of MOE. The study designed the ICSS and developed an instrument to investigate the satisfaction for the teachers of primary schools, junior high schools and senior high schools. By analyzing 253 teachers, the results show that demographics, such as age, school level, teaching experience and position, have significant effects on the ICSS satisfaction. Further, the teachers were found to be satisfied with the system content, system accuracy, report format, ease of use, system timeliness and community building offered by the ICSS that helps us to understand the teachers' online behavior in more detail for the popularization of the course service system.
\end{abstract}

Keywords: online service system; educational six learning networks; course service system; system timeliness and community

\section{Introduction}

An integrated course service system is useful for knowledge generation, teaching and social innovation for sustainability [1]. Social networks are inherent in any e-learning system, and their main actors are teachers, learners and learning resources [2,3]. Therefore, in a digital teaching and learning environment, the teaching resources used for supporting teachers and students are important $[4,5]$. Creating a virtual community of instructors is one strategy for increasing their satisfaction with regards to the digital teaching and learning environment. When the instructors have a sense of belonging to the site, it will foster their willingness to share materials, enhancing their interests in the system service. The knowledge and instructional resources system platform shapes a professional virtual community, and the teachers can share norms, values and professional dialogues with each other $[6,7]$. Anderson and Dron [2] further pointed out that the virtual community may finally form a social 
network to support the digital teaching and learning activities. Thus, the 'School-Teacher's Learning Community' can provide a new path within in-service teachers' education [8,9]. Additionally, the type of presentation of teaching materials is important for course adaptation and can be supported by a course management system [10,11].

In Taiwan, the Ministry of Education (MOE) created a project called the Integrated Course Service System (ICSS), which integrates the Educational Six Learning Networks (ESLN) to support teachers (including primary school, junior high school and senior high school teachers) to search their instructional materials, displaying the resources with personalized requirements. At present, there are 321 schools participating in the ICSS and more than 2600 teachers using the ICSS to help them prepare teaching materials.

Online communities are virtual spaces over the WWW (World Wide Web), in which groups of people with similar interests or purposes interact with others and share information [12-14]. Yilmaz [15] pointed out that users' willingness to share knowledge and high-quality content will influence the successful use of virtual communities. Besides the content quality, Tam and Oliveira [16] also find that system quality and system service are important determinants of members' loyalty to the virtual community. As the virtual communities can offer educators the opportunity to interact with other members, they can create professional virtual communities that allow members to share education-related knowledge [7]. Besides the benefits of getting requested teaching materials, the ICSS can also support teachers to socialize with other members through the virtual community [17].

While exploring the contribution of an IS (Information System), the most commonly used measure of effectiveness within the IS field is user satisfaction $[16,18,19]$. Therefore, satisfaction is often seen as a key variable in predicting the success of an IS or users' reuse behavior [20]. Commonly, the greater the satisfaction users have with their online services, the stronger will be their feelings about its perceived usefulness [21-23]. The measure of satisfaction degree will support the assessment of a successful course service in a teachers' learning community $[8,9]$.

Previous literature has suggested that user satisfaction should cover the entire customer experience cycle from information retrieval through to purchasing, payments, receipts and post-purchase services $[16,18]$. The user satisfaction research developed thus far can generally be conceptualized around two different types of satisfaction: transaction-specific satisfaction and cumulative satisfaction [24-26]. Transaction-specific satisfaction assessment focuses on the user experience in a product episode or service encounter. Cumulative satisfaction focuses on a user's overall experience to date with a product or service provider, rather than on a transient perception of a product or service at any given point in time [27]. Min, Khoon and Tan [28] modified the SERVQUAL framework to evaluate learners' satisfaction, finding that service quality is not just about 'service operation' and 'service process', but also the real benefits of services as products.

Satisfaction refers to a psychological state that is an emotional response. The emotional basis for satisfaction surrounding disconfirmation expectations is confirmed by an individual's prior feelings and responses [29]. IS satisfaction covers the extent to which users believe the IS available to them meets their information requirements [30].

There are few studies that have examined teachers' satisfaction, although instructors' satisfaction is considered as significant for course participation and increasing student connections with the course activity [31].

Bailey and Pearson [32] considered satisfaction under a given situation as the sum of one's feelings or attitudes toward a variety of factors affecting that situation and identified 39 factors that affect satisfaction. This definition, which includes attitudinal and affective responses, is also supported by Doll and his colleagues, who used it to develop their own measurement of user satisfaction [33-35]. Prior studies highlighted course content, the information system and the facility for accessing and visualizing information on the teaching platform-as well as the possibility of interaction-as keys to enhancing their teaching satisfaction $[30,31,36]$. 
This study followed the perspective of Bailey and Pearson [32] and Johnson et al. [27] to measure teachers' satisfaction with the ICSS. Although Doll and Torkzadeh's [34] satisfaction scale is popular and has been verified in the online context, it was developed in an end computer context and remains limited in its ability to measure the communication characters of a virtual community $[37,38]$. Therefore, the study investigated the precise composition of user satisfaction and community building $[39,40]$ to evaluate teachers' satisfaction with the ICSS.

\section{The Implementation of the ICSS}

\subsection{Strategy of ICSS Development}

According to the original concepts and the procedures required for an ICSS user requirements analysis, we interviewed 4 principals, 6 directors of academic affairs, and 10 teachers to determine their requirements for the ICSS. We also sought to identify the resources provided to teachers. Following the interviews, five development strategies of the ICSS were suggested. They were: (1) providing batch functions for the searching of instructional materials; (2) providing a storage and presentation area for instructional materials; (3) reducing the teachers' workloads when they maintain their own school Course Service System (CSS); (4) promoting the use of the ICSS among teachers and providing a convenient search method for instructional materials; (5) facilitating empathic learning on teaching courses and forming a professional virtual community.

\subsection{The Architecture of the ICSS}

The ICSS was developed using Moodle Open Source software to serve teachers of primary schools, junior high schools and senior high schools in Taiwan. With this system, teachers can store and display their instructional materials using a personalized format in the ICSS. Although every school has its own CSS, teachers can participate in empathic learning from other schools' CSSs via the "single sign-on" function authenticated by the external database of Moodle. The architecture of the ICSS is shown in Figure 1 below.

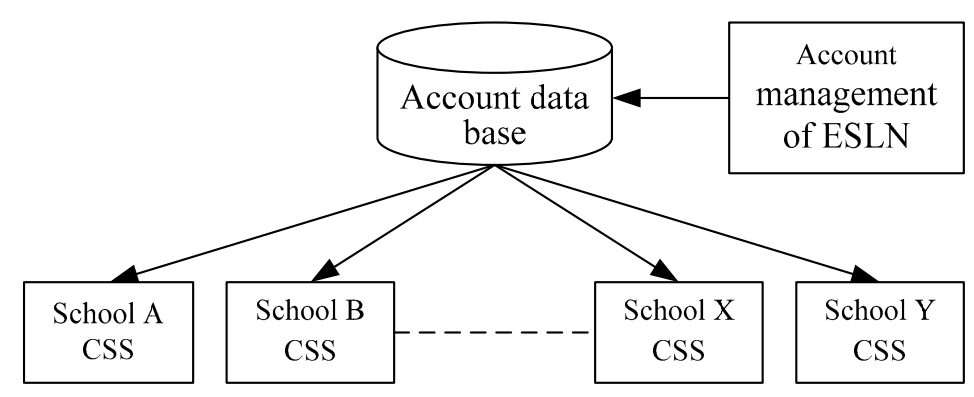

Figure 1. Architecture of the Integrated Course Service System (ICSS).

The searching mechanism for digital instructional materials is presented in Figure 2. The database of the ICSS stores all the metadata of the digital instructional materials within the ESLN. When teachers upload digital instructional material to the ESLN, the metadata of the material is written into the ICSS database automatically. Similarly, when teachers want to search for their instructional materials, they merely input the keywords into their own school CSS, and the digital instructional materials of the ESLN will be searched for. When the searching activities are complete, the digital instructional materials will be presented in the user's personalized format. 


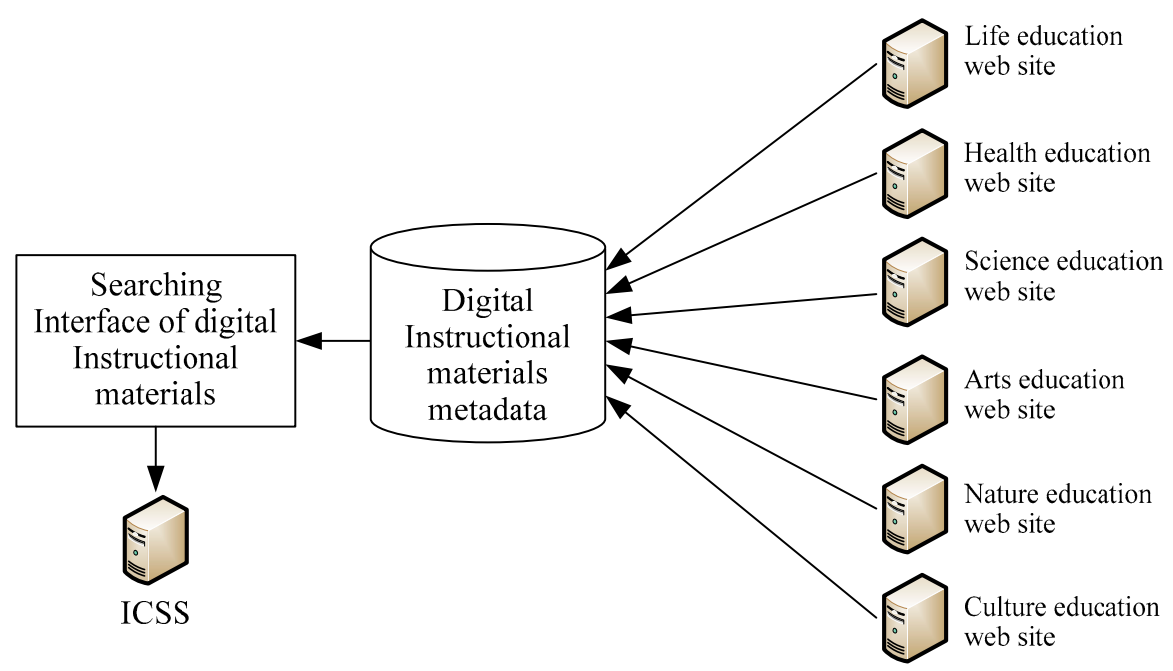

Figure 2. Searching mechanism for digital instructional materials.

\subsection{Processes of Searching}

This study highlights the need to reform interface design based on the syllabus, in order to develop a convenient method of searching for digital instructional materials. Teachers could then enter the keywords to suit their needs. With a personalized interface design, the ICSS could provide a personalized format to display the searched instructional materials. It is proposed here that when teachers want to search for instructional materials, they should follow four stages: first, users would select the import methods for their syllabuses; second, in editing mode, users would modify their syllabus and keywords; third, users would search for and select the necessary instructional materials; and finally, users would export those instructional materials.

\subsection{Operation of the ICSS}

According to the concept of function blocks in the ICSS (see Figure 3), ICSS administrators manage course syllabuses and create/delete the course presentation for each school. The process suggested is represented in Figure 3. Teachers select the edited course to form their course packages. When teachers download the course packages, the ICSS can automatically export those course packages with the Moodle format. Teachers can then use their own school CSS to create a course and then import the course packages into their school CSS. More detailed operations are described below according to a number of steps.

Figure 4 shows the first step in creating a course/import syllabus. At the start of the process, teachers can select a personalized online environment for creating or importing a new course. Once teachers have finalized their selection of a teaching subject and edition of a book, onscreen messages related to the topic, keywords and recommended instructional materials are displayed in the second step (see Figure 5). This approach can avoid verbose key-in processes and reduces time. By tracking teachers' online actions, the ICSS can support knowledge-sharing and achieve the goal of coordinated teaching.

Two sub-functions are provided in the third step. The first is the search for digital materials-after teachers select a keyword (as an example, 'Pi' is showed in Figure 6), the ICSS begins the search. The results of a search are shown in Figure 7. Teachers can view the metadata of instructional materials and select the hyperlink to store their chosen instructional materials. The second sub-function involves the selection of digital materials-with a multiple select function, teachers are able to select multiple instructional materials and classify them. The ICSS will present the selected instructional materials based on their classification and reduce the required search time. Once the search for all keywords is completed, it exports the complete course packages for the selected instructional materials in the fourth step (see Figure 8). 


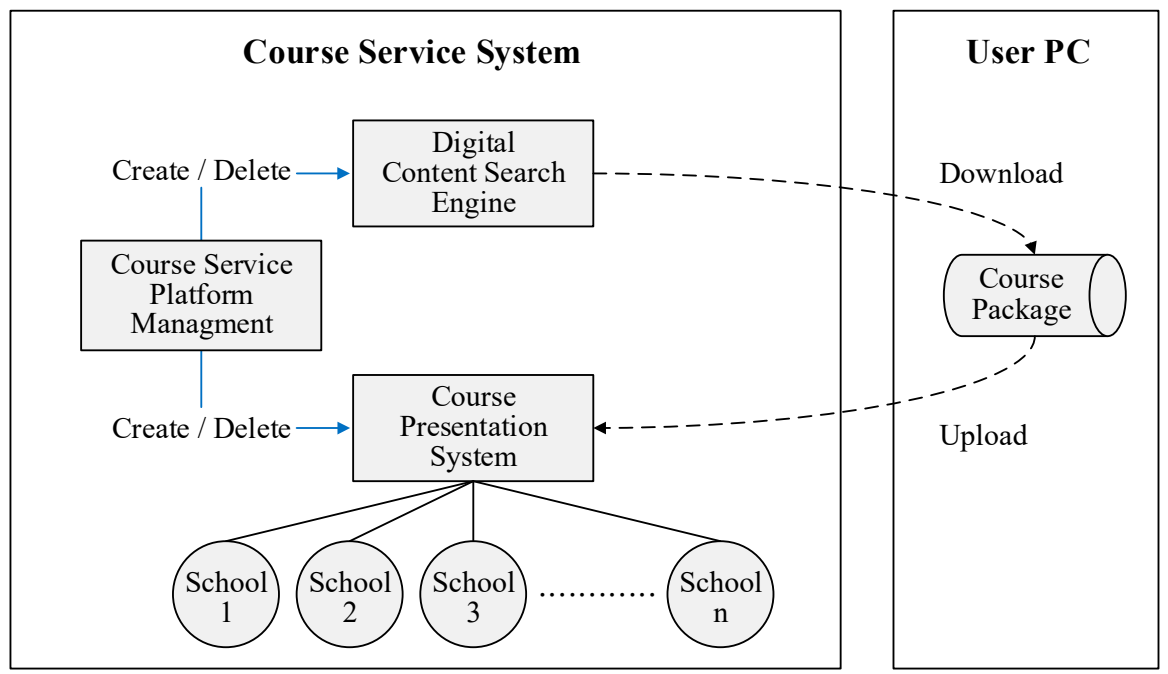

Figure 3. Function blocks of ICSS.

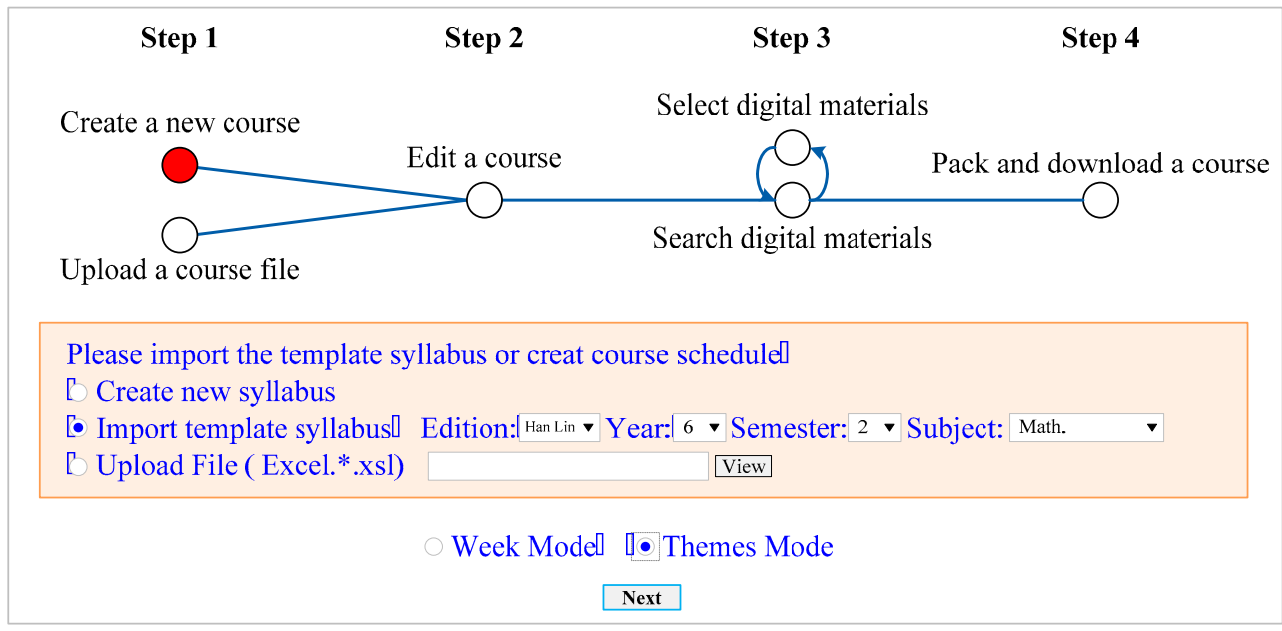

Figure 4. Create/import a new course.

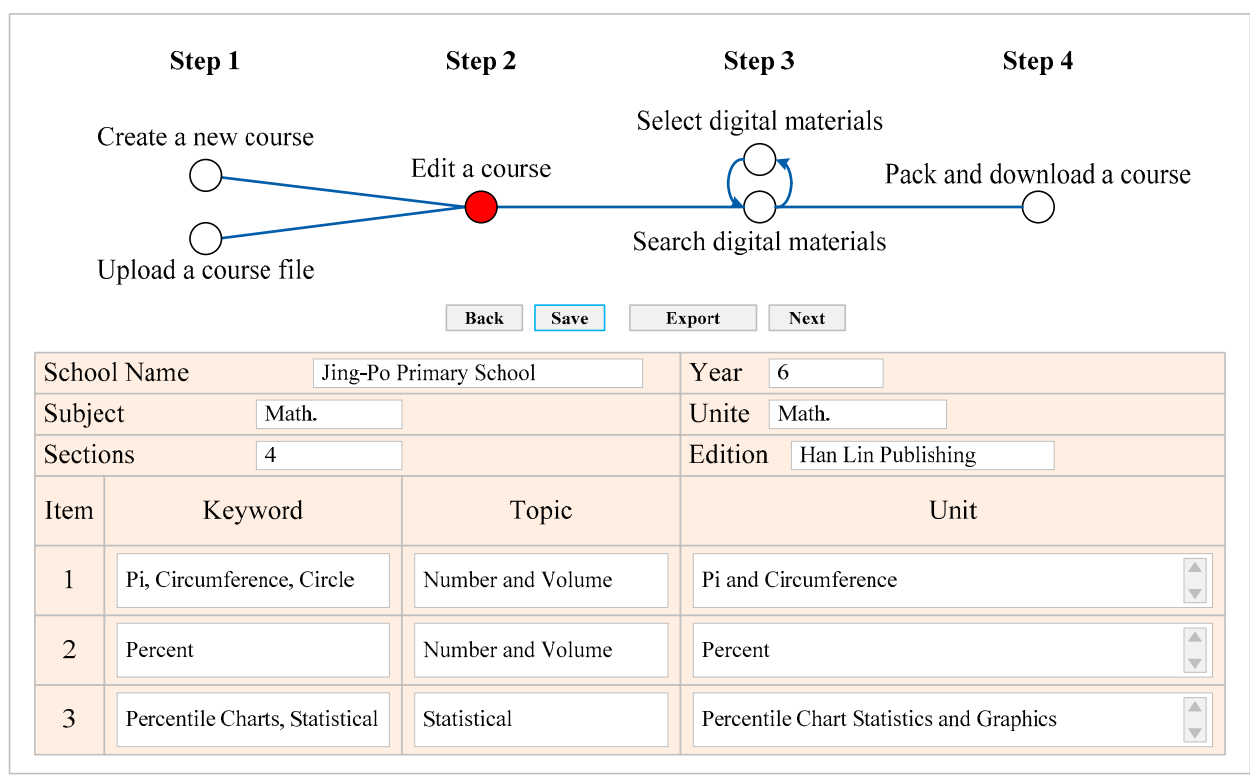

Figure 5. Edit a course. 


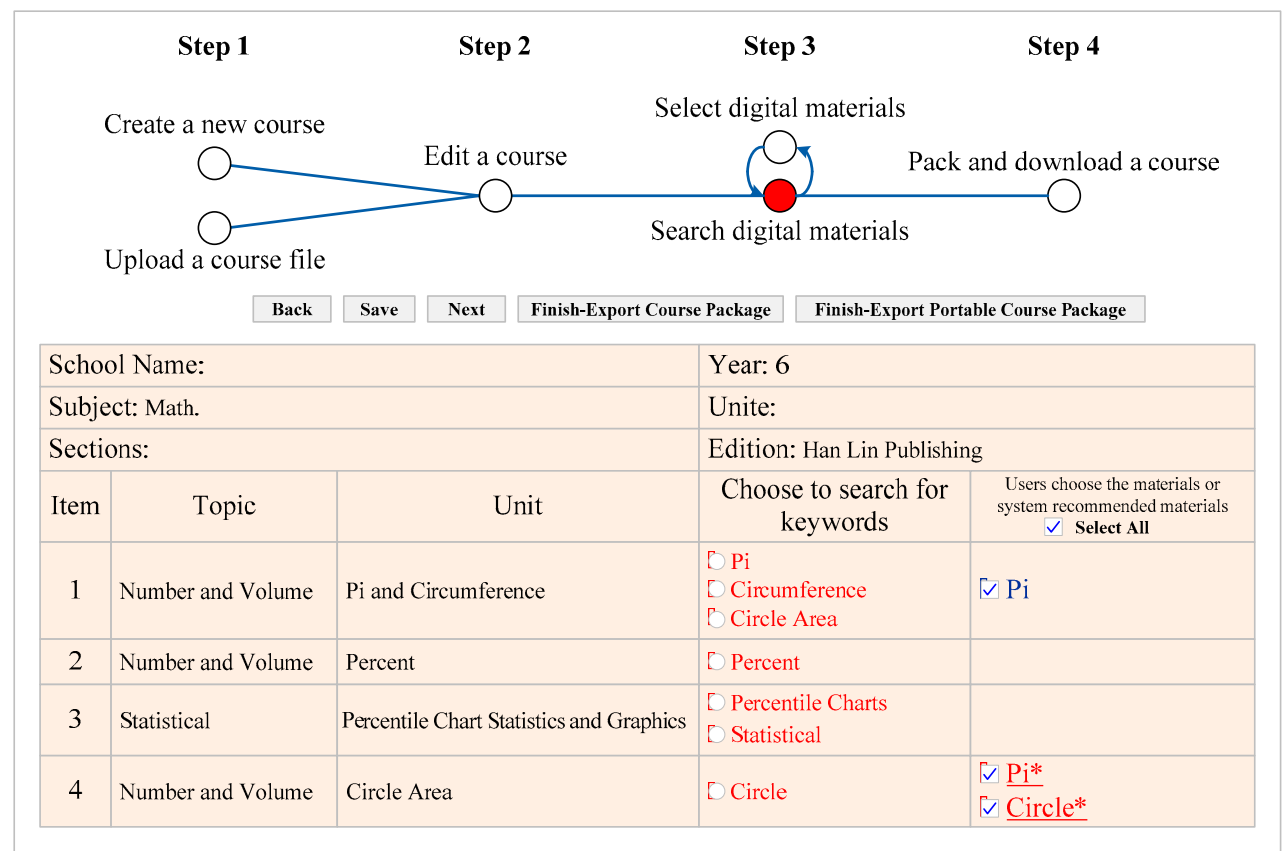

Figure 6. Search digital materials.

\begin{tabular}{l}
\hline \multicolumn{1}{|c|}{ Step 1 } \\
Create a new course
\end{tabular}

Figure 7. Select digital materials.

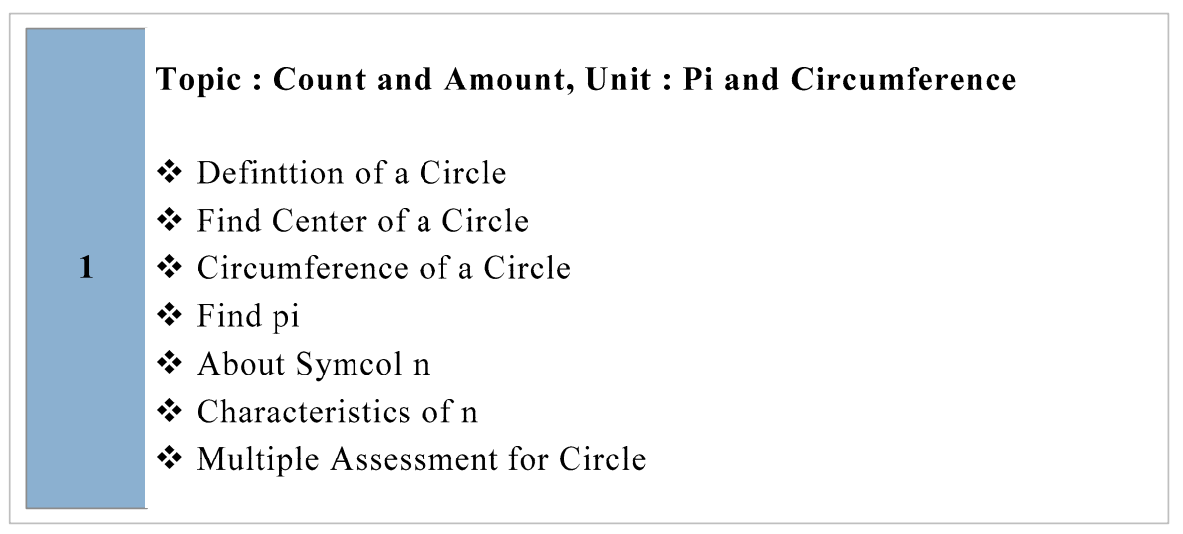

Figure 8. The results of imported course packages. 
As demonstrated in Figure 8, the results show that the topic links to the initial material storage. This approach can promote the utility of instructional materials and provide the records needed for the CSS to analyze the usage of instructional materials.

\section{Methodology}

A measurement of teachers' satisfaction was taken after ICSS implementation. Doll and Torkzadeh's satisfaction scales (regarding system content, system accuracy, report format, ease of use, and system timeliness) [34] are widely used to measure user satisfaction. However, the scales of Doll and Torkzadeh were developed in the context of end user computers, focusing on the interaction between human and machine. In the context of the World Wide Web, the knowledge-sharing via a virtual community involves frequent interactions between individuals. Considering that the ICSS is focused on the sharing of instructional material resources, this study integrated community building with Doll and Torkzadeh's [34] satisfaction scales to measure ICSS user satisfaction. All of the scales were refined by three experts who are experienced with the management of school CSS and three teacher users who are familiar with the ICSS context. The scales were designed as seven-point Likert scales, ranging from 1 for "strongly disagree" to 7 for "strongly agree".

Sample data were collected from the members of the ICSS, who were invited to participate in a web-based survey. Among the 262 received questionnaires, 253 completed questionnaires were used for the analysis.

\section{Reliability and Validity}

Reliability was evaluated by internal consistency, such that a factor's Cronbach's alpha with a value of greater than 0.7 means good reliability [41]. The reliability of each factor is as follows (see Table 1): the global Cronbach's alpha is 0.969 , system content is 0.904 , system accuracy is 0.923 , report format is 0.918 , ease of use is 0.919 , system timeliness is 0.877 , and community building is 0.901 . Therefore, the instrument of this study was found to have good reliability.

Table 1. Reliability and construct validity.

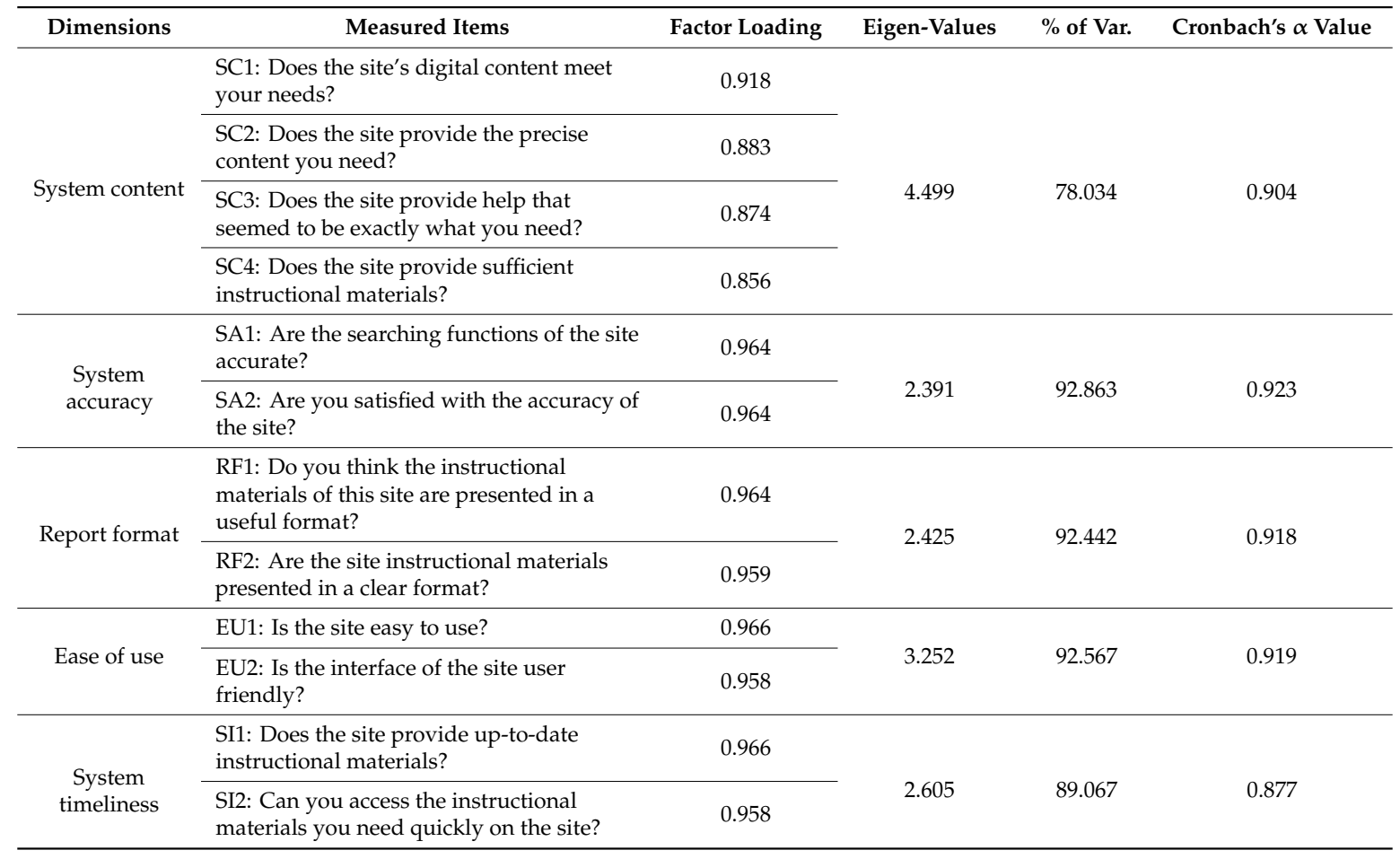


Table 1. Cont.

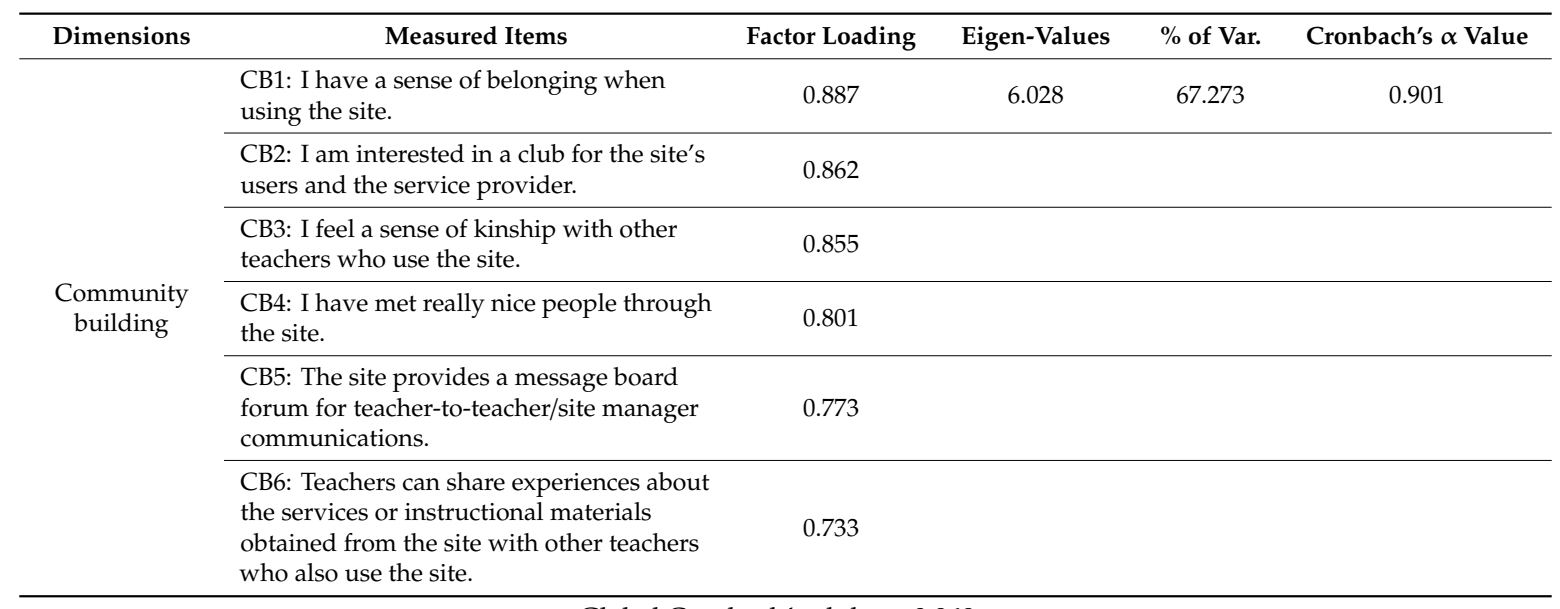

Global Cronbach's alpha $=0.969$.

The basic qualitative criterion concerning validity is content validity. Since there were three experts of digital material design and three teachers who assisted in refining the questionnaire, the instrument of this study can be said to possess content validity. Further, this study adopted exploratory factor analysis (EFA) to verify the construct validity using a varimax rotation. The results of the EFA (see Table 1) revealed that each of the variables demonstrated sufficient construct validity, because the factor loading of each item in the construct is above the recommended cut value of 0.5 - the eigen-value of each variable is greater than 1 [41]. Overall, the results provided empirical support for the scales used to test user satisfaction with the ICSS.

\section{Finding}

As the teacher characteristics relate to the teaching performance and IT use, the six demographics were examined in relation to their impact on teachers' satisfaction with the ICSS. An ANOVA test was conducted, using demographics as the independent variable, and total ICSS satisfaction and each component satisfaction as the dependent variables (i.e., system content, system accuracy, report format, ease of use, system timeliness, and community building). The results for all of the ANOVA tests are shown in Table 2. It appeared that four of the six demographics-age, school level, experienced in teaching, and position - had a significant effect on the total ICSS satisfaction. The factor of gender has no significant association with satisfaction. The possible reason is as follows: the purpose of ICSS is to assist teachers in preparing teaching materials and provide tools for sharing knowledge and experience. In Taiwan, the gender of most of the teachers in primary school and junior high school is female. The study respondents were $34.75 \%$ male and $65.25 \%$ female. These results imply that each teacher has basic information literacy and the ability to use the ICSS. The means of each demographic classification related to the six ICSS satisfaction components are listed in Table 3, and the significant components are discussed in greater detail below. 
Table 2. ANOVA tests of ICSS satisfaction by the $p$ values of demographic variables.

\begin{tabular}{|c|c|c|c|c|c|c|c|c|c|c|c|c|}
\hline $\begin{array}{l}\text { Satisfaction } \\
\text { Components }\end{array}$ & Age & $\begin{array}{l}\text { Effect } \\
\text { Size } \\
\text { (Age) }\end{array}$ & $\begin{array}{l}\text { School } \\
\text { Level }\end{array}$ & $\begin{array}{c}\text { Effect Size } \\
\text { (School } \\
\text { Level) }\end{array}$ & $\begin{array}{l}\text { Experienced } \\
\text { in Teaching }\end{array}$ & $\begin{array}{c}\text { Effect Size } \\
\text { (Experienced } \\
\text { in Teaching) }\end{array}$ & Position & $\begin{array}{c}\text { Effect } \\
\text { Size } \\
\text { (Position) }\end{array}$ & Gender & $\begin{array}{l}\text { Effect } \\
\text { Size } \\
\text { (Gender) }\end{array}$ & $\begin{array}{l}\text { Education } \\
\text { Degree }\end{array}$ & $\begin{array}{c}\text { Effect Size } \\
\text { (Education } \\
\text { Degree) }\end{array}$ \\
\hline System content & $0.007^{\mathrm{a}}$ & 0.012 & $0.000^{\mathrm{a}}$ & 0.012 & $0.008^{a}$ & 0.024 & 0.109 & 0.188 & 0.438 & 0.215 & 0.229 & 0.007 \\
\hline System accuracy & $0.013^{\mathrm{b}}$ & 0.013 & $0.002^{\mathrm{a}}$ & 0.007 & 0.068 & 0.005 & 0.900 & 0.105 & 0.360 & 0.139 & 0.147 & 0.003 \\
\hline Report format & 0.196 & 0.007 & $0.023^{\mathrm{b}}$ & 0.010 & 0.274 & 0.005 & 0.105 & 0.227 & 0.725 & 0.081 & 0.260 & 0.004 \\
\hline Ease of use & $0.001^{\mathrm{a}}$ & 0.008 & $0.019^{\mathrm{b}}$ & 0.002 & 0.080 & 0.013 & 0.120 & 0.135 & 0.824 & 0.048 & 0.253 & 0.005 \\
\hline System timeliness & $0.042^{b}$ & 0.010 & $0.001^{\mathrm{a}}$ & 0.015 & 0.134 & 0.005 & 0.605 & 0.204 & 0.737 & 0.085 & 0.148 & 0.005 \\
\hline Community building & $0.008^{a}$ & 0.010 & $0.007^{\mathrm{a}}$ & 0.004 & $0.018^{\mathrm{b}}$ & 0.009 & 0.643 & 0.207 & 0.629 & 0.134 & 0.296 & 0.004 \\
\hline Total satisfaction & $0.005^{\mathrm{a}}$ & 0.004 & $0.001^{\mathrm{a}}$ & 0.004 & $0.029^{b}$ & 0.011 & $0.043^{\mathrm{b}}$ & 0.231 & 0.718 & 0.080 & 0.169 & 0.009 \\
\hline
\end{tabular}

a Significant at the 0.01 level. ${ }^{\mathrm{b}}$ Significant at the 0.05 level. 
Table 3. Mean analysis of ICSS satisfaction.

\begin{tabular}{|c|c|c|c|c|c|c|c|c|c|}
\hline \multirow{2}{*}{ Demographics } & \multirow{2}{*}{ Categories. } & \multirow{2}{*}{$\begin{array}{c}\text { Frequency } \\
(\%)\end{array}$} & \multicolumn{7}{|c|}{ Means of ICSS Satisfaction } \\
\hline & & & Content & Accuracy & Format & Ease of Use & Timeliness & Community Building & Total Satisfaction \\
\hline \multirow{7}{*}{ Age } & Below 26 years & $7.63 \%$ & 5.13 & 5.24 & 5.43 & 5.26 & 5.06 & 4.95 & 5.18 \\
\hline & 26 30 years & $16.67 \%$ & 4.94 & 5.07 & 5.14 & 4.65 & 4.84 & 4.68 & 4.89 \\
\hline & $31 \sim 35$ years & $24.29 \%$ & 5.03 & 4.92 & 5.17 & 4.90 & 4.98 & 4.83 & 4.97 \\
\hline & $36 \sim 40$ years & $16.1 \%$ & 5.21 & 5.33 & 5.29 & 5.19 & 5.11 & 4.91 & 5.17 \\
\hline & $41 \sim 45$ years & $20.34 \%$ & 5.47 & 5.43 & 5.54 & 5.42 & 5.37 & 5.17 & 5.39 \\
\hline & 46 50 years & $8.76 \%$ & 5.62 & 5.48 & 5.42 & 5.27 & 5.19 & 5.13 & 5.35 \\
\hline & Above 50 years & $6.21 \%$ & 5.56 & 5.66 & 5.66 & 5.77 & 5.64 & 5.50 & 5.63 \\
\hline \multirow{2}{*}{ School level } & Primary school & $64.69 \%$ & 5.40 & 5.33 & 5.43 & 5.25 & 5.29 & 5.08 & 5.29 \\
\hline & Junior high school & $24.86 \%$ & 4.83 & 4.95 & 5.05 & 4.80 & 4.81 & 4.72 & 4.86 \\
\hline \multirow{8}{*}{$\begin{array}{l}\text { Experienced } \\
\text { in teaching }\end{array}$} & Senior high school & $10.45 \%$ & 5.08 & 5.30 & 5.38 & 5.12 & 4.80 & 4.81 & 5.08 \\
\hline & Below 2 years & $12.15 \%$ & 4.88 & 5.06 & 5.16 & 4.93 & 4.90 & 4.80 & 4.95 \\
\hline & $2-5$ years & $14.69 \%$ & 5.22 & 5.15 & 5.28 & 4.97 & 5.05 & 5.04 & 5.12 \\
\hline & $6-10$ years & $21.47 \%$ & 5.23 & 5.14 & 5.31 & 4.91 & 5.12 & 4.95 & 5.11 \\
\hline & $11-15$ years & $19.77 \%$ & 4.97 & 5.06 & 5.15 & 5.09 & 4.94 & 4.66 & 4.96 \\
\hline & $16-20$ years & $18.36 \%$ & 5.49 & 5.52 & 5.51 & 5.38 & 5.26 & 5.14 & 5.38 \\
\hline & 21-25 years & $8.19 \%$ & 5.62 & 5.57 & 5.66 & 5.41 & 5.57 & 5.23 & 5.51 \\
\hline & Above 25 years & $5.37 \%$ & 5.39 & 5.42 & 5.47 & 5.66 & 5.34 & 5.38 & 5.44 \\
\hline \multirow{3}{*}{ Position } & Senior high school & $10.45 \%$ & 5.08 & 5.30 & 5.38 & 5.12 & 4.80 & 4.81 & 5.08 \\
\hline & Administrative teacher & $46.89 \%$ & 5.32 & 5.31 & 5.46 & 5.24 & 5.27 & 5.09 & 5.27 \\
\hline & Pure teacher & $53.11 \%$ & 5.14 & 5.17 & 5.21 & 5.03 & 4.99 & 4.85 & 5.07 \\
\hline \multirow{2}{*}{ Gender } & Male & $34.75 \%$ & 5.28 & 5.31 & 5.301 & 5.15 & 5.09 & 5.00 & 5.19 \\
\hline & Female & $65.25 \%$ & 5.19 & 5.20 & 5.34 & 5.12 & 5.14 & 4.95 & 5.15 \\
\hline \multirow{3}{*}{$\begin{array}{c}\text { Education } \\
\text { degree }\end{array}$} & 5-year junior college & $1.41 \%$ & 5.35 & 4.90 & 5.20 & 5.00 & 5.40 & 5.27 & 5.19 \\
\hline & University & $66.95 \%$ & 5.29 & 5.31 & 5.40 & 5.20 & 5.20 & 5.01 & 5.23 \\
\hline & Master or doctor & $31.64 \%$ & 5.08 & 5.08 & 5.19 & 4.96 & 4.95 & 4.85 & 5.02 \\
\hline
\end{tabular}




\subsection{Age}

Age was significantly associated with total ICSS satisfaction at the 0.01 level. Age was also found to be significantly associated with system content, ease of use and community building at the 0.01 level, and with system accuracy and system timeliness at the 0.05 level. However, the association between age and report format was insignificant. Table 3 further shows the means for different age groups associated with each ICSS satisfaction component. Generally, the results indicate that older teachers have higher ICSS satisfaction levels than their younger counterparts. This finding may be due to the greater opportunity young teachers have to experience and use information technology in daily life. Therefore, young teachers have higher expectations of the ICSS, which explains their lower satisfaction levels. In summary, the ICSS can capture the integrated contributions for older teachers but is yet to adequately capture the needs of younger teachers.

\subsection{School Level}

School level was significantly associated with total ICSS satisfaction at the 0.01 level. Under further analysis, school level was found to have significant associations with system content, system accuracy, system timeliness and community building at the 0.01 level, and with report format and ease of use at the 0.05 level. Table 3 shows that those respondents teaching in primary schools had higher ICSS satisfaction levels. One reason for this is that primary school teachers face less pressure to promote their students to enter high schools than do teachers in junior or senior high schools. They can give more attention to prepare the instructional materials, which in turn increases their satisfaction with the support offered by the ICSS. Another reason is perhaps that the ICSS has, to date, provided more teaching resources for primary schools than for junior or senior high schools. This finding implies that the ICSS should strengthen its service for teachers of junior or senior high schools.

\subsection{Experienced in Teaching}

There was a significant association identified between teachers' teaching experience and total ICSS satisfaction at the 0.05 level. The teaching experience was significantly associated with system content and community building. Simultaneously, insignificant associations were found between teachers' teaching experience and system accuracy, report format, ease of use and system timeliness. Further, the more experienced teachers were more satisfied with the ICSS than were novice teachers. These results imply that experienced teachers are more aware of the support provided by integrated instructional materials and the sharing of teaching activities.

\subsection{Position}

Although a significant association was found between teachers' positions (administrative teacher vs. pure teacher) and total ICSS satisfaction, there appeared to be no association between teachers' positions and any ICSS satisfaction components. As demonstrated in Table 3, the administrative teachers have higher satisfaction levels with the ICSS than do the pure teachers. This result shows that no position differences among teachers affected satisfaction with the ICSS, but that the ICSS can effectively help busy administrative teachers to reduce the time needed to prepare instructional materials.

Table 2 provides the significant result and Table 3 helps us to deeply understand some discrepancies in the different personality traits. According to the Bonferroni correction results, the demographics of age present significant discrepancies in the following factors: ease of use-those aged between 26 and 30 years old have a significantly associated with those aged between 41 and 45 years old $(p=0.006)$; the aged between 26 and 30 years old is significantly associated with those above 50 years old ( $p=0.003$ ); the aged between 31 and 35 years old is significantly associated with those above 50 years old $(p=0.022)$. For system timeliness, the age between 26 and 30 years old has a significantly associated with those aged above 50 years old $(p=0.049)$. In terms of community building, those aged between 26 and 30 years old have a significantly associated with those aged above 50 years old 
$(p=0.016)$, and those aged between 31 and 35 years old have a significantly associated with those above 50 years old $(p=0.027)$. The demographics of school level present significant discrepancies in the following factors: the primary school level is significantly associated with the junior high school level in the factors of system content $(p=0.000)$, system accuracy $(p=0.000)$, report format $(p=0.001)$, ease of use $(p=0.018)$, system timeliness $(p=0.000)$ and community building $(p=0.004)$.

\section{Conclusions}

While the type of content plays an important role in the design of online courses [21], instructional materials on the Internet can help teachers to enrich their design of teaching activities. However, an excess of Internet resources that are not integrated could confuse teachers when searching for materials to assist in the design of their teaching plans. This study implemented an ICSS to assist teachers in searching for their required instructional materials from a distributed ESLN using an integrated approach. Meanwhile, depending on teaching requirements, teachers can use the ICSS to personalize the presentation format for their selected instructional materials.

As the ICSS can benefit teachers by offering them instructional materials in a convenient location, exploring users' satisfaction with the ICSS is important for its continued improvement and promotion. Current mature models of user satisfaction are invariably developed from the environment of end-user computers. For use in online professional discussions and the sharing environment of instructional materials, this study refined a popular satisfaction model proposed by [34]. By adding a new construct of community building, this study developed a measurement instrument and then embarked on an investigation of the satisfaction patterns of teachers from primary schools, and junior and senior high schools.

The results reveal that some demographics, such as age, school level, experience in teaching, and position, have significant effects on total ICSS satisfaction. Among those demographics that impact each satisfaction component, school level was found to have the strongest effect, followed by age and teaching experience. Comparing the three different school levels, we found that primary school teachers were more able to accept innovative teaching activities than junior and senior high school teachers. Therefore, the ICSS must provide users from different school levels and differently aged teachers with different system functions, system contents and knowledge-sharing models according to their needs.

The ICSS can be used to provide an online environment that facilitates interaction among teachers and creates a professional virtual community for them. This community will enable teachers to share and develop their professional knowledge [7]. At the same time, the teachers' responses in this community will allow ICSS developers to gain a better understanding of teachers' preferences toward ICSS features-knowledge that can be applied to continuing improvements or enhancements. This will in turn increase teachers' satisfaction with the ICSS, and thereby increase their acceptance and continued use of the national course service system.

\section{Limitations and Further Research}

In Taiwan, the instructors have the pressure of teaching progress in junior and senior high school. Teachers often use their past teaching experience to conduct course activities, so the flexibility of using ISS to support teaching is limited. On the other hand, booksellers often take the initiative to support the teaching materials and teaching plans of the junior and senior high school teachers. Therefore, teachers who are more passively adding teaching materials have a lower willingness to use ICSS. They are more inclined to actively use ICSS teachers in the selection of subjects. The subjects of the study may be more inclined towards the active use of ICSS teachers. The ICSS has provided teachers with the functions of searching for teaching materials. In the future, the ICSS can customize system interfaces and related functions by personal habits and then enhance their satisfaction. The study can also promote passive teachers to use ICSS, and further conduct the qualitative analysis of ICSS based on the teacher's teaching effectiveness. 
With the advancement of technology, teaching aid systems must be more flexible to support teaching activities. Therefore, a customized system with a customized interface and flexible system function, which is stable and fast, will be the goal of future research efforts.

Author Contributions: M.-H.L.: Conceptualization; M.-C.H.: Data curation; W.-H.H.: Formal analysis; W.-F.H.: Project administration; M.-L.C.: Methodology; S.-T.W.: Review and editing.

Funding: This work was supported by Higher Education Sprout Project, Ministry of Education, Taiwan.

Acknowledgments: We thank the anonymous reviewers for their insightful comments to improve the clarity of the theoretical arguments in the manuscript.

Conflicts of Interest: All of the authors declare that they have no conflict of interest.

\section{References}

1. Tejedor, G.; Segalàs, J.; Barrón, Á.; Fernández-Morilla, M.; Fuertes, M.T.; Ruiz-Morales, J.; Gutiérrez, I.; García-González, E.; Aramburuzabala, P.; Hernández, À. Didactic Strategies to Promote Competencies in Sustainability. Sustainability 2019, 11, 2086. [CrossRef]

2. Anderson, T.; Dron, J. Integrating learning management and social networking systems. Ital. J. Educ. Technol. 2018, 25, 5-19.

3. Lee, Y.; Lim, S. Effects of Sports Activity on Sustainable Social Environment and Juvenile Aggression. Sustainability 2019, 11, 2279. [CrossRef]

4. Byers, T.; Imms, W.; Hartnell-Young, E. Evaluating teacher and student spatial transition from a traditional classroom to an innovative learning environment. Stud. Educ. Eval. 2018, 58, 156-166. [CrossRef]

5. Al-Rahmi, W.M.; Yahaya, N.; Aldraiweesh, A.A.; Alamri, M.M.; Aljarboa, N.A.; Alturki, U.; Aljeraiwi, A.A. Integrating Technology Acceptance Model With Innovation Diffusion Theory: An Empirical Investigation on Students' Intention to Use E-Learning Systems. IEEE Access 2019, 7, 26797-26809. [CrossRef]

6. Mohammadyari, S.; Singh, H. Understanding the effect of e-learning on individual performance: The role of digital literacy. Comput. Educ. 2015, 82, 11-25. [CrossRef]

7. Tsiotakis, P.; Jimoyiannis, A. Critical factors towards analysing teachers' presence in on-line learning communities. Internet High. Educ. 2016, 28, 45-58. [CrossRef]

8. Earp, J.; Ott, M.; Pozzi, F. Facilitating educators' knowledge sharing with dedicated Information Systems. Comput. Hum. Behav. 2013, 29, 445-455. [CrossRef]

9. Callahan, C.; Saye, J.; Brush, T. Interactive and Collaborative Professional Development for In-Service History Teachers. Soc. Stud. 2016, 107, 227-243. [CrossRef]

10. Limongelli, C.; Lombardi, M.; Marani, A.; Sciarrone, F.; Temperini, M. A recommendation module to help teachers build courses through the Moodle Learning Management System. New Rev. Hypermedia Multimed. 2016, 22, 58-82. [CrossRef]

11. Dai, Y.; Hwang, S.-H. Technique, Creativity, and Sustainability of Bamboo Craft Courses: Teaching Educational Practices for Sustainable Development. Sustainability 2019, 11, 2487. [CrossRef]

12. Sharma, S.K.; Joshi, A.; Sharma, H. A multi-analytical approach to predict the Facebook usage in higher education. Comput. Hum. Behav. 2016, 55, 340-353. [CrossRef]

13. Li, C.; Zhou, H. Enhancing the Efficiency of Massive Online Learning by Integrating Intelligent Analysis into MOOCs with an Application to Education of Sustainability. Sustainability 2018, 10, 468. [CrossRef]

14. Chan, M.M.; Plata, R.B.; Medina, J.A.; Alario-Hoyos, C.; Rizzardini, R.H. Modeling Educational Usage of Cloud-Based Tools in Virtual Learning Environments. IEEE Access 2019, 7, 13347-13354. [CrossRef]

15. Yilmaz, R. Knowledge sharing behaviors in e-learning community: Exploring the role of academic self-efficacy and sense of community. Comput. Hum. Behav. 2016, 63, 373-382. [CrossRef]

16. Tam, C.; Oliveira, T. Understanding mobile banking individual performance: The DeLone \& McLean model and the moderating effects of individual culture. Internet Res. 2017, 27, 538-562.

17. McGee, P.; Windes, D.; Torres, M. Experienced online instructors: Beliefs and preferred supports regarding online teaching. J. Comput. High. Educ. 2017, 29, 331-352. [CrossRef]

18. Delone, W.H.; McLean, E.R. Measuring e-Commerce Success: Applying the DeLone \& McLean Information Systems Success Model. Int. J. Electron. Commer. 2004, 9, 31-47. 
19. Organero, M.; Kloos, C.; Merino, P. Personalized Service-Oriented E-Learning Environments. IEEE Internet Comput. 2010, 14, 62-67. [CrossRef]

20. Cidral, W.A.; Oliveira, T.; Di Felice, M.; Aparicio, M. E-learning success determinants: Brazilian empirical study. Comput. Educ. 2018, 122, 273-290. [CrossRef]

21. Liu, I.-F.; Chen, M.C.; Sun, Y.S.; Wible, D.; Kuo, C.-H. Extending the TAM model to explore the factors that affect Intention to Use an Online Learning Community. Comput. Educ. 2010, 54, 600-610. [CrossRef]

22. Elliott, M.; Rhoades, N.; Jackson, C.; Mandernach, J. Professional Development: Designing Initiatives to Meet the Needs of Online Faculty. J. Educ. Online 2015, 12, 160-188. [CrossRef]

23. Wu, I.-L.; Chen, K.-W.; Chiu, M.-L. Defining key drivers of online impulse purchasing: A perspective of both impulse shoppers and system users. Int. J. Inf. Manag. 2016, 36, 284-296. [CrossRef]

24. Johnson, M.D.; Anderson, E.W.; Fornell, C. Rational and Adaptive Performance Expectations in a Customer Satisfaction Framework. J. Consum. Res. 1995, 21, 695-707. [CrossRef]

25. Shahijan, M.K.; Rezaei, S.; Guptan, V.P. Marketing public and private higher education institutions: A total experiential model of international student's satisfaction, performance and continues intention. Int. Rev. Public Nonprofit Mark. 2018, 15, 205-234. [CrossRef]

26. Pritchard, A.; Fudge, J.; Crawford, E.C.; Jackson, J. Undergraduate choice of major and major satisfaction: An expanded role for personality measures. J. Mark. High. Educ. 2018, 28, 155-174. [CrossRef]

27. Johnson, M.D.; Gustafsson, A.; Andreassen, T.W.; Lervik, L.; Cha, J. The evolution and future of national customer satisfaction index models. J. Econ. Psychol. 2001, 22, 217-245. [CrossRef]

28. Min, S.; Khoon, C.C.; Tan, B.L. Motives, Expectations, Perceptions and Satisfaction of International Students Pursuing Private Higher Education in Singapore. Int. J. Mark. Stud. 2012, 4, 122. [CrossRef]

29. Ali, F.; Amin, M.; Cobanoglu, C. An integrated model of service experience, emotions, satisfaction, and price acceptance: An empirical analysis in the Chinese hospitality industry. J. Hosp. Mark. Manag. 2016, 25, 449-475. [CrossRef]

30. Al-Samarraie, H.; Teng, B.K.; Alzahrani, A.I.; Alalwan, N. E-learning continuance satisfaction in higher education: A unified perspective from instructors and students. Stud. High. Educ. 2017, 43, 2003-2019. [CrossRef]

31. Almarashdeh, I.; Almarashdh, I. Sharing instructors experience of learning management system: A technology perspective of user satisfaction in distance learning course. Comput. Hum. Behav. 2016, 63, 249-255. [CrossRef]

32. Bailey, J.E.; Pearson, S.W. Development of a Tool for Measuring and Analyzing Computer User Satisfaction. Manag. Sci. 1983, 29, 530-545. [CrossRef]

33. Doll, W.J.; Raghunathan, T.S.; Lim, J.S.; Gupta, Y.P. A confirmatory factor analysis of the user information satisfaction instrument. Inf. Syst. Res. 1995, 6, 177-188. [CrossRef]

34. Doll, W.J.; Torkzadeh, G. The Measurement of End-User Computing Satisfaction. MIS Q. 1988, 12, $259-274$. [CrossRef]

35. Doll, W.J.; Deng, X.; Raghunathan, T.; Torkzadeh, G.; Xia, W. The Meaning and Measurement of User Satisfaction: A Multigroup Invariance Analysis of the End-User Computing Satisfaction Instrument. J. Manag. Inf. Syst. 2004, 21, 227-262. [CrossRef]

36. Martín-Rodríguez, Ó.; Fernández-Molina, J.C.; Montero-Alonso, M.Á.; González-Gómez, F. The main components of satisfaction with e-learning. Technol. Pedagog. Educ. 2015, 24, 267-277. [CrossRef]

37. Chaparro, B.S.; Farmer, S.M.; Abdinnour-Helm, S.F.; Abdinnour-Helm, S.F. Using the End-User Computing Satisfaction (EUCS) Instrument to Measure Satisfaction with a Web Site. Decis. Sci. 2005, 36, 341-364.

38. Thielsch, M.T.; Hirschfeld, G. Facets of website content. Hum.-Comput. Interact. 2019, 34, 279-327. [CrossRef]

39. Tsai, H.-T.; Huang, H.-C. Determinants of e-repurchase intentions: An integrative model of quadruple retention drivers. Inf. Manag. 2007, 44, 231-239. [CrossRef]

40. Wang, W.-T.; Ou, W.-M.; Chen, W.-Y. The impact of inertia and user satisfaction on the continuance intentions to use mobile communication applications: A mobile service quality perspective. Int. J. Inf. Manag. 2019, 44, 178-193. [CrossRef]

41. Hair, J.F.; Black, W.C.; Babin, B.J.; Anderson, R.E.; Tatham, R.L. Multivariate Data Analysis; Pearson: Uppersaddle River, NJ, USA, 2006.

(C) 2019 by the authors. Licensee MDPI, Basel, Switzerland. This article is an open access article distributed under the terms and conditions of the Creative Commons Attribution (CC BY) license (http://creativecommons.org/licenses/by/4.0/). 